\title{
RISK ANALYSIS OF SHALLOT FARMING IN MALANG REGENCY, INDONESIA
}

\author{
M. Zul Mazwan*, Jabal Tarik Ibrahim, Wahyu A. M. Fadlan \\ Agribusiness Department, Faculty of Agriculture and Animal Science/ University of Muhammadiyah Malang \\ *corresponding author: mzulmazwan@umm.ac.id
}

\begin{abstract}
This study was aims to 1) determine the amount of shallot farming income, 2) analyze the risk of production and income of shallot farming. The location of the research was purposively conducted. The type of data is primary data obtained from 80 samples farmers in the study area. Farming analysis was applied to knowing shallot farming income. Furthermore, coefficient of variation (CV) was applied to knowing the risk of production and income. The results showed that $\mathrm{R} / \mathrm{C}$ ratio as many as 2.11 . With that result, it can be said that shallot farming in Malang Regency is feasible. The level of production risk is $37.54 \%$ and the level of risk income is $40 \%$. It can be concluded that the risk of production and income of shallot farming during the dry season in Malang Regency is included in the low category.
\end{abstract}

Keywords: Coefficient Variation, Income Risk, Production Risk, Shallot

http://dx.doi.org/10.21776/ub.agrise.2020.020.3.3

Received 28 March 2020

Accepted 29 June 2020

Available online 29 July 2020

\section{INTRODUCTION}

Agriculture is the main livelihood source for the majority of the Indonesian people, which has a large role in the economy in Indonesia (Statistics Indonesia, 2018). The contribution of the agricultural sector in economic development lies in five terms, those are; provides a growing food surplus to an increasing population, increases the demand for industrial products so as to encourage the expansion of the secondary and tertiary sectors, provides additional foreign exchange income for the import of capital goods for development through continuous export of agricultural products, increases village income, and improves the welfare of rural people (Jhingan, 2007). As one of most Indonesian people basic needs, shallot become ONE of the priority commodities in Indonesia.

Malang Regency is one of the shallot production center in East Java. Beside Nganjuk Regency which has as many as 38,051 ton and Probolinggo Regency as many as 6,046 ton of shallot production, Malang Regency has as many as 2,597 ton shallot production, followed by Kediri Regency which has 1,162 ton shallot production (Statistics Indonesia, 2018). Shallot production has experienced a surplus. Ideally if it has a surplus, shallot exports will increase. However, in reality shallot imports were quite high and have increased. This is due to the low quality factor and the high price of local shallots (Kementerian Perdagangan Republik Indonesia, 2019). Tabel 1.1 below explains the increasing production of shallots in Malang Regency each year.

Tabel 1. Shallot Production in Malang Regency Year of 2016-2017

\begin{tabular}{ccc}
\hline Year & Harvested Area & Production (qu) \\
\hline 2014 & 821 & 70,945 \\
2015 & 1,090 & 78,309 \\
2016 & 4,222 & 350,777 \\
2017 & 4,124 & 412,592 \\
2018 & 4,743 & 494,783
\end{tabular}

Source: Secondary Data of BPS, 2018.

The information above indicates that shallot farming has a serious income risk. According to (Rini Mutisari, 2019), shallot farming risk can occur during the production process and during the process of determining the selling price. Saptana et al., (2010) ) added that external factors of shallot 
farming risk are shown through climate / weather changes, pest attacks, price of production facilities, and output prices. While internal factors of shallot farming risk are indicated through the availability of land tenure capital and managerial capabilities. high or low risk of farming will affect farmers in making farming decisions. Therefore this study aims to 1) determine the amount of shallot farm income, 2) determine the level of production and income risk in shallot farming.

\section{RESEARCH METHODS}

\section{Location and Research Time}

The research was determined purposively in Purworejo Village, Ngantang District, Malang Regency. Purworejo village was chosen based on consideration of the location is one of the villages of shallot production centers in Malang Regency. The time of the study was conducted in September 2018 to November 2018.

\section{Samples of Study}

The sampling method is a purposive sampling method with criteria 1) farmers who are members of farmer groups 2) farmers who are active in activities in farmer groups. Determination of the minimum sample size of researchers using the Slovin model (Setiawan, 2007), the formula:

$$
\begin{aligned}
n & =\frac{N}{1-N e^{2}}=\frac{380}{1-380(0,1)^{2}} \\
& =\frac{380}{1-3,8}=\frac{380}{4,8}=79,16
\end{aligned}
$$

where,

$1=$ a constant

$\mathrm{n}=$ sample

$\mathrm{N}=$ population

$\mathrm{e}^{2}=$ inaccuracy due to sampling errors that can be tolerated in $10 \%$ with a reliance level of $90 \%$

The minimum number of samples obtained was 79.16 and rounded up to a minimum of 80 samples. The data used in this study are primary and secondary data. Primary data was collected using interview, observation, questionnaire, and documentation techniques. While secondary data was collected using literature review.

\section{Method of Analysis}

a. Cost Analysis

Production cost analysis consist of two kinds cost, namely fixed costs and variable costs. Total fixed costs and total variable costs are the total costs of production. The formulation is:

$\mathrm{TC}=\mathrm{TFC}+\mathrm{TVC}$

where,

$\mathrm{TC}=$ Total Cost

TFC $=$ Total Fixed Cost

TVC $=$ Variable Cost b. Revenue Analysis

Farm receipts are the result of multiplication between the amount of production and the selling price of the product. To find out the acceptance of onion farming can be calculated using the formula:

$\mathrm{TR}=\mathrm{P} \times \mathrm{Q}$.

where,

$\mathrm{TR}=$ Total Revenue = Total Revenue

$\mathrm{P}=$ Selling Price $(\mathrm{Rp} / \mathrm{kg})=$ Selling Price $(\mathrm{Rp} / \mathrm{kg})$

$\mathrm{Q}=$ Production quantity $(\mathrm{kg})$

c. Income Analysis

Farm income is derived from total revenue minus total costs.

Income $=\mathrm{TR}-\mathrm{TC}$

where,

$\mathrm{TR}=$ Total Revenue

$\mathrm{TC}=$ Total Cost

$=$ Total Revenue $=$ Total Cost

d. Analysis of Farming Efficiency

Analysis of efficiency can be done after after obtaining value from cost analysis and income analysis. The amount of farm efficiency can be calculated from the ratio between the amount of revenue and the costs incurred for production with the $\mathrm{R} / \mathrm{C}$ ratio. Based on this statement the $\mathrm{R} / \mathrm{C}$ ratio can be formulated:

$\mathrm{R} / \mathrm{C}$ ratio $=\frac{T R}{T C}$

where,

$\mathrm{R} / \mathrm{C}$ ratio $=$ Farming Efficiency

$\mathrm{TR}=$ Total Revenue

TC $=$ Total Cost

After getting the $\mathrm{R} / \mathrm{C}$ ratio, there are several criteria for assessing whether the farm is efficient or not. The testing criteria are:

$\mathrm{R} / \mathrm{C}<1$ means inefficient or unprofitable farming

$\mathrm{R} / \mathrm{C}=1$ means farming at the breakeven point

$\mathrm{R} / \mathrm{C}>1$ means efficient or profitable farming

e. Risk of Shallot Farming Analysis

This analysis is used to determine the level of production and income risk in shallot farming. The level of shallot farming risk is identified by looking at the magnitude of the coefficient of variation $(\mathrm{CV})$. The coefficient of variation $(\mathrm{CV})$ is the relative level of risk obtained by dividing the standard deviation of income by the expected value. Mathematically the formula is as follows:

$\mathrm{CV}=\frac{\sigma}{\bar{\pi}}$.

where $\mathrm{CV}$ is coefficient of variation, $\sigma$ is standard deviation and $\bar{\pi}$ is average production or income of shallot farming in $\mathrm{Rp}$ or $\mathrm{Kg}$. The criteria that can be deduced from the calculated coefficient of variation are as follows:

1) $\mathrm{CV}<0,5$ means that shallot farming in the study area has a low risk

2) $\mathrm{CV}>0,5$ means that shallot farming in the study area has a high risk. 


\section{RESULTS AND DISCUSSION}

\section{Shallot Farming Analysis}

a. Fixed Cost

Fixed costs that are calculated in onion farming are land tax, and depreciation of equipment (sprayer and hoe). Based on the results of the study, the average land tax in the study area was Rp 303,188.00. The average of land tax value in 1 ha conversion was $\mathrm{Rp}$ $614,826.00$. While the average cost of tool depreciation on shallot farming was Rp 233,000.00 with an average cost of $\mathrm{Rp} 46,663.00$ in 1 ha conversion. The tools used in shallot farming include sprayers and hoes. Farmers in the village do not need to pay irrigation fees. Irrigation is regulated by dividing water according to the area of land owned by each farmer. Total Fixed Cost incurred by respondent farmers is obtained from the sum of land tax and tool depreciation. The result is $\mathrm{Rp}$ 536,188.00 and $\mathrm{Rp} 1,061,489.00$ when converted in 1 ha.

\section{b. Variable Cost}

Variable Cost consist of the cost of purchasing agricultural production facilities such as seeds, fertilizers, pesticides, and labor costs. The variable costs incurred by farmers are as follows:

Seedling cost, generally, farmers in Purworejo Village use shallots seeds of Batu Ijo variety. Shallot seeds are bought in kilos. The price of a kilo of shallot seeds is Rp 12,000. Seedling costs incurred by shallot farmers depend on the area of land. The average seedling costs incurred by farmers are $\mathrm{Rp}$ $14,355,000.00$ and Rp. 32,290,060.00 in one ha conversion.

Fertilizer cost, mostly, organic fertilizer used in the study area is manure derived from dried chicken manure. Because of various government education and guidance, farmers prioritize the use of organic fertilizer. Organic fertilizers produce higher quality shallots. Meanwhile, to maintain the quality of soil fertility, farmers use organic fertilizers, ZA, Urea, Phonska and TSP.

Table 2. Average of Fertilizer Costs per Ha in One Growing Season

\begin{tabular}{lcrr}
\hline Fertilizer & $\begin{array}{c}\text { Cost/Unit } \\
(\mathrm{Rp})\end{array}$ & Quantity/Unit & $\begin{array}{c}\text { Total Cost } \\
(\mathrm{Rp})\end{array}$ \\
\hline Organic & 17,000 & 141.25 & $2,401,250$ \\
ZA & 80,000 & 3.94 & 260,000 \\
Urea & 90,000 & 1.90 & 119,813 \\
Phonska & 115,000 & 2.79 & 320,563 \\
TSP & 102,000 & 3.49 & 276,038 \\
\hline \multicolumn{1}{c}{ Total } & & & $3,377,663$ \\
\hline
\end{tabular}

Source: Data Process (2018)

Organic fertilizer is the fertilizer most widely used by shallot farmers in Purworejo Village. The average use of organic fertilizer is 141.25 bags, while ZA is 3.94 bags, Urea 1.90 bags, Phonska 2.79 bags, TSP
3.49 bags in which 1 bag contains $50 \mathrm{~kg}$. The average fertilizer costs incurred by farmers is $\mathrm{Rp}$ $2,401,250.00$ and $\operatorname{Rp~} 7,319,456.00$ in one ha conversion.

Pesticide costs, the use of fertilizer must be balanced with the use of pesticides. Shallots are very susceptible to pests and diseases that require intensive treatment. There are 2 types of pesticides used, namely Pesticides for insects (Insecticides) and Pesticides for fungi (Fungicides). Farmers in Purworejo Village use 2 types of Pesticides, namely Insecticides and Fungicides. Based on the table 5.8., pesticides with brand Dupont Prevathon $250 \mathrm{ml}$ (Insecticide) and Daconil 500 gr (Fungicide) are pesticides that are widely used by shallot farmers in Purworejo Village. The average of total cost for pesticides is Rp 992,125.00 and if converted into one hectare an average of $\operatorname{Rp} 2,113,825.00$ is obtained.

Table 3. Average of Pesticide Cost per Ha in One Growing Season

\begin{tabular}{lrrr}
\hline Pesticide & \multicolumn{1}{c}{$\begin{array}{c}\text { Cost/Unit } \\
(\mathrm{Rp})\end{array}$} & $\begin{array}{c}\text { Quantity/ } \\
\text { Unit }\end{array}$ & \multicolumn{1}{c}{$\begin{array}{c}\text { Total Cost } \\
(\mathrm{Rp})\end{array}$} \\
\hline Spontan & $50,000.00$ & 1.72 & $46,250.00$ \\
Prevathon & $135,000.00$ & 2.72 & $312,188.00$ \\
Tornado & $60,000.00$ & 2.19 & $52,500.00$ \\
Antracol & $60,000.00$ & 3.88 & $151,500.00$ \\
Unilax & $60,000.00$ & 2.93 & $33,000.00$ \\
Mankozeb & $85,000.00$ & 3.31 & $126,438.00$ \\
Daconil & $115,000.00$ & 4.09 & $270,250.00$ \\
\hline \multicolumn{1}{c}{ Total } & & 21 & $992,125.00$ \\
\hline
\end{tabular}

Source: Data Process (2018)

Labor cost, shallot cultivation activities in Purworejo Village include land management, planting, maintenance, fertilizing and harvesting. Generally, farmer labor in Purworejo Village is carried out by outside family. Some farmer labor is also taken from the family. Farmer workers also come from neighboring villages. The system used for wage labor is a daily system. Labor costs for male worker are $\mathrm{Rp} 50,000.00$ per day and for female workers Rp 30,000.00 per day. The amount of labor used in shallot farming depends on the area of land owned by the farmer.

Table 4. Average of Labor Cost per $\mathrm{Ha}$ in One Growing Season

\begin{tabular}{lrr}
\hline \multirow{2}{*}{ Labor Total } & \multicolumn{2}{c}{ Labor Quantity \& Cost } \\
\cline { 2 - 3 } & \multicolumn{1}{c}{ Male } & \multicolumn{1}{c}{ Female } \\
\hline Labor Quantity & 427 & 406 \\
(Person) & 20.95 & 18.53 \\
Workday (Days) & & $2,858,250$ \\
Wage (Rp/Season) & $5,720,000$ & \\
\hline
\end{tabular}

Source: Data Process (2018) 
The number of female workers is more than the number of male workers. The difference is 21 people. but the total wages of male labor are greater because men's daily wages are greater than women. Men work days (HOK) Men take longer because of the different types of work performed. The average total labor cost is $\mathrm{Rp} 8,578,250.00$ and when converted into one hectare it becomes $\mathrm{Rp}$ 19,248,175.00.

Total variable cost spent by the respondent farmers is the sum of seed costs, fertilizer costs, labor costs, and pesticide costs. The total variable cost is $\operatorname{Rp} 2,184,243,000.00$ with an average variable cost is $\operatorname{Rp} 27,303,038.00$. If converted into one hectare, total variable cost of $\mathrm{Rp}$ $4,962,640,361.00$ is obtained with an average of $\mathrm{Rp}$ $62,033,005.00$.

\section{c. Total Cost Analysis in Shallot Farming}

The average total fixed cost in the form of land tax and tool depreciation is $\operatorname{Rp} 536,188.00$, while the average of total variable cost in the form of seed, fertilizer, pesticide and labor costs is $\mathrm{Rp}$ 27,303,038.00. Depreciation of the equipment (sprayer and hoe) is calculated based on its useful life, the sprayer is calculated to last its useful time in 1 year (3 times growing season), while the hoe has a useful time of 1 year too. Depreciation of other agricultural equipment is not taken into account, because the agricultural equipment used is the property of farm laborers so that its use is carried by the farm laborer.

\section{d. Revenue Analysis in Shallot Farming}

Net income or profits derived from the difference between total revenue with total production costs. The average income earned by shallot farmers is $\mathrm{Rp}$ $30,694,525.00$ and if converted into one hectare an average of $\mathrm{Rp} 66,616,863.00$ is obtained. This research was conducted by Susanawati et al. (2018). The income earned by shallot farmers is quite large, because farmers in Purworejo village experience the advantage when doing onion farming.

\section{e. R/C Ratio Analysis of Shallot Farming}

The efficiency of shallot farming can be seen from the $\mathrm{R} / \mathrm{C}$ ratio value. $\mathrm{R} / \mathrm{C}$ ratio is the relationship between revenue and production results with costs incurred for the production process. $\mathrm{R} / \mathrm{C}$ ratio is obtained from the division between revenue and total costs. Based on the results of the study, the average of $\mathrm{R} / \mathrm{C}$ ratio was 2.11 . When $\mathrm{R} / \mathrm{C}$ ratio is greater than one $(>1)$, it can be said that shallot farming in the study area is feasible to be cultivated. $\mathrm{R} / \mathrm{C}$ ratio is greater than one $(>1)$ categorized as very beneficial. R / C Ratio 2.11 is interpreted when the costs incurred in the amount of Rp1, the revenue obtained is Rp2.11. The results of this study is similar to previous study conducted by Nurhapsa et al. (2015), where the result of $\mathrm{R} / \mathrm{C}$ ratio was 2.11 . Shallot farming feasible and profitable to cultivate in every season (Aldila et al., 2015).

\section{f. Shallot Farming Risk Analysis}

In farming risk analysis this study is look for both risk of production and income. Because the size of production and income risk will affect farmers' behavior in decision making (Erny et al., 2019). Based on Table 2, the coefficient of variation from production risk is 37.54 percent (less than 50\%). This value can be interpreted that the production risk of shallot farming in the study area has a low value of variation. The value of this variation occurs in the dry season.

This is contrary to the situation in the rainy season. According to Lawalata (2017), in the rainy season with high rainfall intensity will cause humid conditions on agricultural land, so the risk value of shallot production obtained is higher compared to the dry season. Resmayeti Purba (2014) revealed that the optimum shallot production is affected by the growing season. The planting in July-September is the best season, while planting in JanuaryFebruary is the worst season. This is in accordance with the experience of farmers. Based on the experience of farmers, the dry season is the most appropriate season for shallot cultivation. In the dry season crop failure can be reduced.

According to Widyantara \& Yasa (2013), the more experienced farmers in shallot farming, the less risk they face because farmers are more aware of climate conditions. So they have the ability anticipate climate changes in their region. Like creating the enabling environment that will ensure that the menace of pests and diseases are minimized (Benjamin et al., 2018). Astuti et al., (2019) \& Fauzan (2016) add that the production risk that causes a decrease in the quality of onion production can be reduced by applying appropriate cultivation and post-harvest technology. Rauf, Darman, and Atik Andriana (2015) added that the strategy for the development of shallot farming is to improve human resources capacity through training and extension on organic agricultural technology and to use quality seeds for increasing production. 
Table 5. Production and Income Risk in Shallot Farming

\begin{tabular}{lcr}
\hline \multicolumn{1}{c}{ Description } & $\begin{array}{c}\text { Production } \\
\text { Risk }\end{array}$ & $\begin{array}{c}\text { Income } \\
\text { Risk }\end{array}$ \\
\hline Average & 5,321 & $30,694,525$ \\
Standard of Deviation & 1,998 & $12,130,230$ \\
Coefficient of & 0.375 & 0.40 \\
Variation & 4 & 40 \\
CV $(\%)$ & 37.54 & 40 \\
\hline
\end{tabular}

Source: Data Process (2018)

The coefficient of variation of income risk is $40 \%$. That can be interpreted that the level of income risk of shallot farming in the study area is in the low category. The coefficient of variation of income risk is aligned with coefficient of variation of production risk. The greater the risk of crop failure will have an impact on the risk of shallot farming income (Hasan et al., 2016). The variation of price received by farmers are not diverse and tend to be the same (Hemas et al., 2019). This happens because production and prices are more stable in the dry season.

According to Zuhriyah \& Happy (2012) and Budiningsih \& Pujiharto (2006) the biggest factors that cause risk are pests attack, followed by high input prices and low selling price of shallots. Related to those matters, in carrying out shallot farming, it is highly recommended to pay attention to the combination of the use of both quantity and price inputs in order to achieve maximum output. Lawalata (2017) adds that production risk and income risk can be reduced with the efficient use of appropriate inputs.

\section{CONCLUSION}

The average of total production costs incurred by shallot farmers in Malang Regency is Rp $27,303,038.00$. The average amount of revenue received by farmers is $\mathrm{Rp} 58,533,750.00$. The average number of farmers' income earned is Rp $30,694,525.00$. The feasibility of onion farming in the research location is 2.11 , so it can be said to be feasible. While the level of production and income risk of shallot farming in Malang Regency is included in the low category. This is because the farming is done during the dry season, so that pests do not attack as much as during the rainy season. The level of efficiency in the use of production inputs also plays a role in the size of the risk of onion farming.

\section{REFERENCES}

Aldila, H. F., Fariyanti, A., \& Tinaprilla, N. (2015). Analisis Profitabilitas Usahatani Bawang Merah Berdasarkan Musim di Tiga Kabupaten Sentra Produksi di Indonesia. SEPA, 11(2), 249-260.

Astuti, L. T. W., Daryanto, A., Syaukat, Y., \& Daryanto, H. K. (2019). Analisis Resiko Produksi Usahatani Bawang Merah pada Musim Kering dan Musim Hujan di Kabupaten Brebes. Jurnal Ekonomi Pertanian Dan Agribisnis, 3(4), 840-852. https://doi.org/10.21776/ub.jepa.2019.003.04. 19

Benjamin, Y. F., Grace, O., Kwame, O. S., \& Payne, D. L. (2018). The Present Status of Shallot ( Allium ascalonicum L .) Farming Enterprise in The Present Status of Shallot ( Allium ascalonicum L .) Farming Enterprise in Ghana: The Case of Keta Municipality. Agricultural Communication, 5(2), 8-16.

Budiningsih, S., \& Pujiharto. (2006). Analisis Risiko Usahatani Bawang Merah Di Desa Klikiran Kecamatan Jatibarang Kabupaten Brebes. Agritech, VIII(1), 127-143.

Erny, Darwanto, D. H., Masyhuri, \& Waluyati, L. R. (2019). Farmer's Behavior Towards Lembah Palu Shallot Farm Risks in Central Sulawesi, Indonesia. EurAsian Journal of BioSciences, 13, 931-936.

Fauzan, M. (2016). Pendapatan, Risiko dan Efisiensi Ekonomi Usahatani Bawang Merah di Kabupaten Bantul. AGRARIS: Journal of Agribusiness and Rural Development Research, 2(2), 107-117. https://doi.org/10.18196/agr.2231

Hasan, F., Darwanto, D. H., Masyhuri, \& Adiyoga, W. (2016). Risk Management Strategy on Shallot Farming in Bantul and Nganjuk Regency. Ilmu Pertanian (Agricultural Science), 1(2), 80-87.

Hemas, B. S., Santoso, S. I., \& Roessali, W. (2019). Shallot Farming Productivity and Farmer Income Affected by Water Resources Distance in Wanasari. Agroland, 6(2), 81-88.

Jhingan, M. . (2007). Ekonomi Pembangunan dan Perencanaan. Raja Grafindo.

Kementerian Perdagangan Republik Indonesia. (2019). Analisis Outlook Pangan 2015-2019. Pusat Kebijakan Perdagangan Dalam Negeri, Badan Pengkaijan Dan Pengembangan Kebijakan Perdagangan Kementerian Perdagangan.

Lawalata, M. (2017). Risiko Usahatani Bawang Merah di Kabupaten Bantul. Jurnal Agrica, 10(2), 56. https://doi.org/10.31289/agrica.v10i2.924

Nurhapsa, Kartini, \& Arham. (2015). Analisis 
Pendapatan Dan Kelayakan Usahatani Bawang Merah Di Kecamatan Anggeraja Kabupaten Enrekang. Jurnal Galung Tropika, 4(3), 137-143.

Rauf, R. A., Darman, S., \& Atik Andriana. (2015). Pengembangan Usahatani Bawang Merah Varietas Lembah Palu Dan Strategi Analisis SWOT. Agriekonomika, 4, 245-257.

Resmayeti Purba. (2014). Produksi Dan Keuntungan Usahatani Empat Varietas Bawang Merah Di Luar Musim (Off-Season) Di Serang, Banten. Agriekonomika, 3, 55-64.

Rini Mutisari, D. M. (2019). Analisis Risiko Produksi Usahatani Bawang Merah di Kota Batu. Jurnal Ekonomi Pertanian Dan Agribisnis, 3, 655-662.

Saptana, Daryanto, A., Daryanto, H. K., \& Kuntjoro. (2010). Strategi Manajemen Resiko Petani Cabai Merah Pada Lahan Sawah Dataran Rendah Di Jawa Tengah. Jurnal Manajemen \& Agribisnis, 7(2), 115-131.

Setiawan, N. (2007). Penentuan Ukuran Sampel Memakai Rumus Slovin Dan Tabel KrejcieMorgan. Universitas Padjadjaran.
Statistics Indonesia. (2018). Penduduk 15 Tahun Ke Atas yang Bekerja Menurut Lapangan Pekerjaan 2011-2018. BPS.

Susanawati, Jamhari, Masyhuri, \& Dwidjono Hadi Darwanto. (2018). Factors Influencing Income of Shallot Farming in Java Indonesia Using UOP Profit Function Model. Atlantis Press, 172, 68-74.

Widyantara, W., \& Yasa, N. (2013). Iklim Sangat Berpengaruh Terhadap Risiko Produksi Usahatani Bawang Merah (Allium Ascalonicum L). E-Journal Agribisnis Dan Agrowisata (Journal of Agribusiness and Agritourism), 2(1), 32-37.

Zuhriyah, A., \& Happy, A. (2012). Perilaku petani bawang merah dalam mereduksi risiko sebagai upaya untuk meningkatkan produktivitas usahatani (Studi kasus di Kecamatan Batumarmar Kabupaten Pamekasan). Jurnal Rekayasa, 5(2), 78-86. 